\title{
TITLE:
}

\section{Composition of the Fixed Sea Urchin colony on Hatakejima Island, 1977 and 1982}

\section{$\operatorname{AUTHOR}(S)$ :}

Imafuku, Michio; Imaoka, Tohru

\section{CITATION:}

Imafuku, Michio ... [et al]. Composition of the Fixed Sea Urchin colony on Hatakejima Island, 1977 and 1982. PUBLICATIONS OF THE SETO MARINE BIOLOGICAL LABORATORY 1983, 28(5-6): 445-446

ISSUE DATE:

1983-12-26

URL:

http://hdl.handle.net/2433/176064

RIGHT: 


\section{Composition of the Fixed Sea Urchin colony on Hatakejima Island, 1977 and 1982}

In 1977, the examination was carried out on June 2 from 11:30 to 12:30 under the waether of a light rain with a slightly strong breeze from the southeast. The lowest water was $-7 \mathrm{~cm}$ at 12:03. The result is shown in Table 1. An extreme decrease in number was observed in Anthocidaris crassispina; the total number of this species had never been reduced less than 200. The cause of the reduction is thought to be attributable to artificial effect made by local people who are occasionally seen collecting sea urchins around Tanabe Bay including Hatakejima Island at the time of spring tide. Such reduction in number of Anthocidaris made the ratio of the number of Echinostrephus to that of Anthocidaris (E/A) very high to be 6.097, the value having never been obtained. It had fallen between 0.6 and 2.0 since 1963 when the examination had started.

In 1982, the examination was made on June 22 from 12:00 to 13:00. The lowest water was $-7 \mathrm{~cm}$ at $12: 33$ and the weather was fine with a light breeze. The result is shown in Table 2. One of characteristic features observed in 1982 was disappearance of Echinometra mathaei. This had been expected before the examination as the authors had been informed by Mr. Nakashima staying at the Seto Marine Biological Laboratory that this species had not been found in intertidal zones around the laboratory since the last winter probably because of cold water, but still survived

Table 1. Population composition in the fixed echinid colony in 1977.

\begin{tabular}{lrrrrrr}
\hline \multicolumn{1}{c}{ 1977, June 2 } & $\begin{array}{c}\text { Section 1 } \\
\text { (SW) }\end{array}$ & $\begin{array}{c}\text { Section 2 } \\
(\mathrm{NW})\end{array}$ & $\begin{array}{c}\text { Section 3 } \\
\text { (SE) }\end{array}$ & $\begin{array}{c}\text { Section 4 } \\
\text { (NE) }\end{array}$ & Total & Percent \\
\hline Anthocidaris crassispina & 17 & 15 & 22 & 8 & 62 & 13.4 \\
Echinostrephus aciculatus & 69 & 166 & 81 & 62 & 378 & 81.6 \\
Echinometra mathaei & 7 & 4 & 7 & 5 & 23 & 5.0 \\
\hline
\end{tabular}

Table 2. Population composition in the fixed echinid colony in 1982.

\begin{tabular}{lcrrrrr}
\hline 1982, June 22 & $\begin{array}{c}\text { Section 1 } \\
\text { (SW) }\end{array}$ & $\begin{array}{c}\text { Section 2 } \\
(\mathrm{NW})\end{array}$ & $\begin{array}{c}\text { Section 3 } \\
(\mathrm{SE})\end{array}$ & $\begin{array}{c}\text { Section 4 } \\
\text { (NE) }\end{array}$ & Total & Percent \\
\hline Anthocidaris crassispina & 72 & 52 & 73 & 64 & 261 & 30.5 \\
Echinostrephus aciculatus & 134 & 118 & 228 & 114 & 594 & 69.4 \\
Hemicentrotus pulcherrimus & 0 & 1 & 0 & 0 & 1 & 0.1 \\
\hline
\end{tabular}

Publ. Seto Mar. Biol. Lab., XXVIII (5/6), 445-446, 1983.

(Biological data) 
below the low tide mark. Another characteristic feature was reappearance of Hemicentrotus pulcherrimus since 1973. A single individual of this species was observed in a hollow in section II (NW). The E/A ratio was 2.267 .

No Mespilia globulus was found in 1977 or 1982.

Michio Imafuku and Tohru Imaoka 